\title{
The Effect of Corporate Governance Medied by Capital Adequacy and Credit Risk on Financial Performance (Study on Commercial Banks Listed on the Indonesia Stock Exchange)
}

\author{
Ari Data; Rolens E. H. Riwu Manu; Yeheskial Nggandung \\ Economic Education Study Program, Faculty of Teacher Training and Education, Nusa Cendana University \\ Adisucipto Street, Penfui Kupang City, East Nusa Tenggara Indonesia
}

\begin{abstract}
This study discusses the causal relationship between bank corporate governance, capital adequacy and the probability of bank failure due to credit risk from the creditor's perspective on the bank's financial performance. The probability of failure of commercial banks in measuring risk-taking behavior. The special characteristics of commercial banks with smaller board sizes, shareholder equity, and long-term loans are associated with significantly lower levels of credit risk. Larger supervisory boards and short-term debt are associated with lower levels of credit risk.This study aims to examine and prove the effect of corporate governance on capital adequacy, and corporate governance directly and mediated by capital adequacy and credit risk impact on financial performance. Test and prove that corporate governance affects credit risk. Test and prove the effect capital adequacy to credit risk, as well as capital adequacy directly and mediated by credit risk have an impact on financial performance. Test and prove the effect of credit risk on financial performance. The analysis technique uses Generalized Structured Component Analysis (GSCA). The unit of analysis is 30 conventional commercial banks listed on the Indonesia Stock Exchange for the period 2016-2020, using panel data, namely time series and cross sectional data, with a number of observations of $30 \times 5$ years $=150$ financial statements. The findings of this study are expected to contribute to the development of science in the study of financial management, especially the theory of corporate governance and credit risk management, namely: corporate governance as a source of value creation, ensuring capital adequacy as a buffer for the risk of losing credit portfolios and managing credit risk at a minimum level. to maintain financial stability and increase Profit which ensures financial performance remains in good or healthy condition. This study concludes that corporate governance has a significant influence on capital adequacy and financial performance, because good corporate governance will manage an optimal capital structure and the availability of capital adequacy that makes the company more able to operate and invest optimally, so as to generate maximum profit to improve financial performance. The influence of corporate governance on bank financial performance is also mediated by capital adequacy. Corporate governance has no significant effect on credit risk. Corporate governance cannot determine credit risk, because credit risk is the responsibility of company management in order to control risk in banking operations. Capital adequacy has a significant influence on credit risk and financial performance, because capital adequacy for the company's operations and investments will improve the bank's financial performance. Capital adequacy has a direct and mediated effect of credit risk on financial performance. Sufficient capital is able to reduce credit risk and improve financial performance, because credit risk which has a negative impact on financial performance has been successfully reduced.
\end{abstract}

Keywords: Corporate Governance, Capital Adequacy, Credit Risk, Financial Performance.

DOI: $10.7176 /$ RJFA/12-20-06

Publication date:October $31^{\text {st }} 2021$

\section{Introduction}

The main function of commercial banks is to borrow from their customers to provide loans to other parties who need funds, so that banks are always faced with the risk of default as the main risk of the banking sector. A large number of bank loans became bad loans and caused a financial crisis. The probability of default increases and creditors also gradually lose the confidence of the bank, leading to an important restructuring of the banking sector. The main task of bank managers and owners is to reduce credit risk through one of the corporate governance tools. Effective corporate governance must increase investor confidence in the country's economy.

Corporate governance aims to build credibility, ensure transparency and accountability, and maintain effective information disclosure channels to promote better corporate performance. A study by Gompers et al. (2003) during the 1990s revealed that companies with strong governance characteristics can generate abnormal returns of $8.5 \%$ per year. The most common corporate governance practice in the business objective is to maximize shareholder wealth, the main responsibility of management should be to ensure the interests of shareholders. The most serious disadvantage of this corporate governance is that it ignores the wealth of other stakeholders such as employees, customers, creditors. Debt holders have priority right of payment in the event of bankruptcy, but must bear a higher risk of default when the firm has an incentive to invest in high-risk projects 
with the expectation of higher returns. If the project is successful, then shareholders will benefit, as a result, shareholder-oriented corporate governance can damage the value of the company and harm debt holders (Dao and Pham, 2015).

Corporate governance structure and short-term debt are associated with lower levels of credit risk. The special characteristics of commercial banks with smaller board sizes, shareholder equity, and long-term loans are associated with significantly lower levels of credit risk. Larger supervisory boards and short-term debt are associated with lower levels of credit risk. For centuries of banking credit risk probabilities, lenders have had great hopes in developing tools or strategies to assess credit risk and forecast the debtor's failure to guarantee cash inflows.

The term "credit risk" has become one of the most problematic banking terms worldwide which is regularly observed and discussed in many financial articles and research journals. Credit risk is the possibility that a borrower will default on all types of debt due to financial constraints. Default is the debtor's failure to pay part or all of the principal and interest to the lender, but also the risk of a decline in the borrower's credit position resulting in credit risk. Failure does not always occur, but the probability of failure increases.

In times of financial crisis, thousands of businesses and individuals went bankrupt, the lack of cash flow to repay loans made banks hit by bad loans. Bank credit risk is considered as the main characteristic of liquidity panic in times of financial crisis. There is no single corporate governance model that can be applied to all companies. The novelty of this research is to reconstruct various previous research models in the financial and banking sector, become a new research model, and complete the "research gap" that existed in previous studies. Empirically tested the effect of corporate governance mediated by capital adequacy and credit risk on financial performance, which to the researcher's knowledge has never been studied in previous studies. This study discusses the causal relationship between corporate governance and bank capital adequacy, the probability of bank failure due to credit risk from the creditor's perspective on the bank's financial performance. Cumulative failure probabilities and failure distances were estimated for a sample of commercial banks to measure risktaking behavior.

\subsection{Research Problem}

1) Does corporate governance have an influence on capital adequacy?

2) Does corporate governance have an influence on credit risk?

3) Does corporate governance have a direct and mediated effect on capital adequacy and credit risk on financial performance?

4) Does capital adequacy have an influence on credit risk?

5) Does capital adequacy have a direct and mediated effect of credit risk on financial performance?

6) Does credit risk have an influence on financial performance?

\subsection{Research Objectives}

1) Examine and explain the effect of corporate governance on capital adequacy.

2) Examine and explain the effect of corporate governance on credit risk.

3) Examine and explain the influence of corporate governance directly and mediated by capital adequacy and credit risk on financial performance.

4) Test and explain the effect of capital adequacy on credit risk.

5) Examine and explain the effect of adequacy directly and mediated by credit risk on financial performance.

6) Test and explain the effect of credit risk on financial performance.

\section{Literature Review}

\subsection{Corporate Governance}

\subsubsection{The Shareholder Model (Milton Friedman, 1970)}

The shareholder model of corporate governance is used to explain the formal system of accountability of senior management to shareholders. The shareholder theory states that the only responsibility of a business is to increase shareholder wealth which is judged by its market value. Managers and boards of directors will be encouraged to align with shareholder wealth. The problem that underlies corporate governance in this model stems from the relationship between principal and agent that arises when there is a separation between beneficial ownership and executive decision making (Dao and Pham, 2015).

The principal agency problem is also an important element of the expert view of corporate contracts called "incomplete contracts" as developed by Coase (1937), Jensen and Meckling (1976), Fama and Jensen (1983), Williamson (1975, 1985), Aghion and Bolton (1992), and Hart (1995). This principal-agent problem would not arise if it were possible to write "complete contracts" to motivate managers to act in the best interests of shareholders. An effective corporate governance framework can minimize agency costs and problems associated with the separation of ownership and control. "The governance structure can be seen as a decision-making 
mechanism that has not been defined in the original contract".

\subsubsection{Stakeholder Model}

The stakeholder model takes a broader view of the company, namely that corporate governance often describes a network of relationships, both internal and external, involving the corporation. The company is accountable to a wider range of stakeholders other than shareholders. Other stakeholders may include contract partners such as employees, suppliers, customers, creditors, and social constituents such as members of the communities in which the company is located, environmental interests, local and national governments, and society at large. Corporations must be "socially responsible" institutions, which are managed in the public interest. The question of who the stakeholders are is still controversial.

Managers in organizations have a network of relationships to serve that include employees, shareholders, suppliers, business partners and contractors. This theory differs from agency theory which suggests that there is a contractual relationship between managers and shareholders; where managers have the sole goal of maximizing shareholder wealth (Dao and Pham, 2015).

\subsubsection{Agency Theory}

Agency theory is rooted in the economic theory expressed by Alchian and Demsetz (1972) and further developed by Jensen and Meckling (1976). Agency theory assumes that there is a conflict of interest between managers and shareholders of large corporations as a result of the separation of ownership from control. Managers are sometimes motivated to pursue self-interest, which may conflict with the owner's profit maximization goal. The agency relationship paradigm between shareholders (principals) and managers (agents) is thwarted by conflict (Festus et al., 2019).

Agency theory suggests that ownership determines how firms are controlled, which assumes that each party seeks to maximize its own wealth. The level of ownership concentration is a significant factor of shareholders seeking to monitor managers and implement corporate governance mechanisms. The level of concentrated share ownership is higher and has more power to control the company (Shleifer and Vishny, 1997).

\subsection{Conceptual Development and Research Hypothesis}

The mechanism of corporate governance in the banking sector through various perspectives is defined as risk management. One of the well-known measures of risk management, regulated banks is the Capital Adequacy Ratio (CAR), which measures the bank's capital on risk-weighted assets (Dao and Hoang, 2012). In relation to the research objectives, this study adopts agency theory because it focuses on the board of commissioners, audit committee and board of directors as the mechanism that dominates the corporate governance literature. Agency theory further explains the relationship between the provider of corporate finance and the management trusted to manage the affairs of the company, according to the work of Ross (1973); Fama and Jensen (1980); Anderson et al. (2004) and Sanda et al. (2005). Regulation and corporate governance must be recognized as external drivers in various ways that have a positive impact on bank shareholders and managers (Ciancianelli and Gonzales, 2000). In terms of the regulatory system, investors depend on the government to ensure their bank deposits from management takeovers. The relationship between corporate governance, capital adequacy, credit risk and financial performance is defined in the development of the concept, as follows:

\subsubsection{The Effect of Good Corporate Governance on Capital Adequacy}

The implementation of good corporate governance will lead to an optimal capital adequacy ratio. Good corporate governance as a source of value creation, ensuring the availability of capital adequacy as a buffer against the risk of loss in the credit portfolio, operational efficiency to increase profit, and managing credit risk at a minimum level to maintain profit growth to maintain the bank's financial stability.

Hypothesis 1: Corporate governance has an influence on capital adequacy.

\subsubsection{The Effect of Corporate Governance on Credit Risk}

The implementation of good corporate governance will lead to effective risk management in maintaining low credit risk and good bank financial performance; therefore, the two factors are naturally interrelated. The relationship between the two represents a trade-off of risk and return. When the bank can reduce its risk, then the opportunity to improve performance is higher. Better bank risk management in controlling relative risk at a low level and avoiding conflicts of interest between stakeholders will improve bank performance and reputation and corporate image in the eyes of banking stakeholders. Lenders (depositors) will charge lower fees, because they bear less risk. Banks also get more opportunities to increase productive assets so that bank profitability is higher (Cebenoyan and Strahan 2004). Based on the theoretical explanation, the research hypothesis is formulated as follows:

Hypothesis 2: Corporate governance has an influence on credit risk.

\subsubsection{The Effect of Corporate Governance on Financial Performance}

The principles of good corporate governance can improve financial performance, increase competitiveness, credibility and harmonization of relationships between stakeholders in the company, such as investors, creditors, business partners, employees, customers, and others. Companies that apply the principles of good corporate 
governance will result in higher net profit margins and higher earnings per share (Todorovic, 2013).

Kumar and Nihalani (2014) examined the effect of corporate governance on the performance of Bank India and found that the board of directors has played an important role in the company's performance, but the board of directors meeting has a negative effect on financial performance. Based on the explanation of agency theory and previous empirical studies that corporate governance affects financial performance, the following research hypotheses are formulated:

Hypothesis 3: Corporate governance has a direct influence and is mediated by capital adequacy and credit risk on financial performance.

\subsubsection{The Effect of Capital Adequacy on Credit Risk}

The capital adequacy ratio is a measure of a bank's financial strength expressed by the ratio of capital (net worth and subordinated debt) to risk-weighted credit exposure in the form of loans (Economic Times Bureau, 2010). Capital adequacy ratio is calculated by dividing total shareholder equity by total assets. A high capital adequacy ratio indicates that the owner of the bank has a larger share than creditors in the bank's assets. Credit risk is obtained by dividing the loan loss reserve by the total loan portfolio. A high credit risk index indicates that banks have a higher level of problematic loans (Mendoza and Rivera, 2017).

Bearing Risk Theory (Hawley, 1900) explains that an important function of an entrepreneur is to take risks, a function that cannot be delegated to others, profit is a reward for taking risks. Some risks are inherent in any business enterprise in view of the speculative nature of the business. So, in the banking business, management must bear the risk to earn a return in return for taking the risk. The level of risk varies in different businesses, but there is a positive relationship between risk and return (Hawley, 1900). If the risk and cost of capital is managed properly and appropriately, it can reduce failure. Based on the theoretical explanation, the research hypothesis is formulated as follows:

Hypothesis 4: Capital adequacy has an effect on credit risk.

\subsubsection{The Effect of Capital Adequacy on Financial Performance}

Capital adequacy is an important variable in determining the financial performance of banks and banks with large capital can give a signal to the market that the performance is better than the expected average (Flamini et al., 2009). Banks that have large capital are less risky and produce lower profitability ratios because they are considered safer, so there could be a negative relationship between capital adequacy and profit. A higher equity to assets ratio will result in lower external funding requirements and therefore higher financial performance which indicates higher financial performance (Naceur, 2003).

Overall, banks with large capital are believed to reduce funding costs and reduce the possibility of bankruptcy. It is important for banks to examine more deeply if additional equity capital will result in higher financial performance than increased debt. Banks need to ensure the implementation of strict internal processes in lending operations and improve internal controls in preventing risks such as loans (Mendoza and Rivera, 2017).

Capital Adequacy Ratio (CAR) is a ratio used to measure capital adequacy that supports bank assets that can have risks such as loans. The formula for calculating CAR is capital divided by risk-weighted assets. According to regulation No.15/12/PBI/2013 from Bank Indonesia, banks are required to provide a minimum capital of $8 \%$ of risk-weighted assets (RWA). An increase in the CAR ratio means that the amount of capital increases and this indicates that the bank can survive even if it suffers losses. This can increase the level of trust of customers and investors to deposit money. An increase in bank deposits can serve as funds that will be provided as bank loans and so that the bank's ability to generate profits will also increase. The theoretical implication of this empirical is that capital adequacy will improve financial performance. Based on the explanation of the concept of capital adequacy and previous empirical studies that capital adequacy affects financial performance, the following research hypotheses are formulated:

Hypothesis 5: Capital adequacy has a direct and mediated effect of credit risk on financial performance.

\subsubsection{The Effect of Credit Risk on Financial Performance}

The risk associated with the banking sector business is defined as a decrease in the value of the company, due to changes in the business environment. Credit risk affects the profitability, operational efficiency and stock prices of banks, because an increasing NPL and LLP ratio will reduce the bank's potential income, and be an indication that the bank is inefficient. This condition gives a negative signal to the market which causes investors to sell banking shares, which then has an impact on the decline in the share price. If the NPL and LLP ratios decrease or improve, it will have a positive effect on increasing profitability, operational efficiency and provide a positive signal to the market so that investors are interested in buying the bank's shares (Amidu and Robert, 2006; Mbarek and Hmaied, 2011; and Epure and Esteban, 2011). 2013).

Risk is the uncertainty of the position of the actual return on investment that is different from the expected return (Alshatti, 2015). Risk occurs due to investment decisions and funding decisions of companies that have the opportunity to lose the original investment and the amount of interest accumulated in it. Credit risk is the risk that the borrower defaults and does not honor his obligations to pay the debt. Credit risk can occur when partners 
cannot pay or cannot pay on time.

Credit risk is the risk of losing principal or forfeiting financial rewards stemming from the borrower's failure to repay a loan or fulfill a contractual obligation (www.Investopedia.com, Dec 23, 2020). Credit risk arises whenever a borrower expects to use future cash flows to repay current debt. Investors are compensated by assuming credit risk by means of interest payments from the borrower or issuer of debt obligations, and credit risk is the potential for loss of return on investment, the most important of which is that the yield of bonds is strongly correlated with perceived credit risk (www.investopedia.com, Dec 23,2020 ).

Credit risk management affects the financial performance of banks, therefore management should be careful in regulating credit policies (Nawaz and Munir, 2012). Liquidity and bank size greatly affect the effectiveness of credit risk management (Abdelrahim, 2013). Risk management indicators (doubtful loans, and capital asset ratios) have an effect on bank performance (Adeusi et al., 2013). Unwise borrowing has a negative effect on net interest margin (Berrios, 2013). Credit risk indicators have a negative effect on bank performance (Kaaya and Pastory, 2013). Concluded that bank financial performance is influenced by credit risk management and capital adequacy (Ogboi and Unuafe, 2013).

Non-Performing Loans (NPL) is the level of non-performing loans of banks. The smaller the NPL ratio, the wiser the bank is in providing credit to customers and this is with the aim of achieving the right target (Christaria and Kurnia, 2016). This practice leads customers and investors to believe that money deposited in the bank will be properly managed thereby, increasing the bank's ability to generate profit using its assets. This means that the bank's financial performance as a proxy for ROA will also increase. According to Regulation No.15/2/PBI/2013 from Bank Indonesia, the ratio of non-performing loans should not exceed 5\% of total loans (Haneef et al., 2012).

Banks must establish an appropriate credit risk environment; the bank operates in accordance with the guidelines for providing sound credit; maintain appropriate credit administration involving monitoring; processing and control of credit risk, and banks need to put in place and develop strategies that will not only limit the bank's exposure to credit risk, but will develop the bank's performance and competitiveness (Alshatti, 2015). It is critical for banks to understand which risk factors have a greater influence on financial performance and use better risk-adjusted performance measures to support the strategy. Banks must establish credit risk management in establishing the process from initiation to loan approval, taking into account sound credit risk management practices issued by regulations (Mendoza and Rivera, 2017). The theoretical implication of this empirical is credit risk will reduce financial performance. Based on the explanation of the concept of credit risk and previous empirical studies that credit risk affects financial performance, the following research hypotheses are formulated:

Hypothesis 6: Credit risk has an influence on bank financial performance.

\section{Research Methods}

\subsection{Types of Research}

This type of research is explanatory, namely explaining the influence between one or several variables with one or several other variables, using secondary data. Based on the research model that has been developed, it is expected to be able to further clarify the influence between the variables analyzed, and at the same time be able to make useful research implications for the development of science as well as a method for solving problems in the field. Quantitative research methods are based on the philosophy of positivism, which is used to examine certain samples or populations, by collecting data, data analysis is quantitative/statistical, with the aim of testing hypotheses (Data et al., 2017).

\subsection{Location, Population and Research Sample}

The location of this research is in Indonesia and the object of observation is all conventional commercial bank companies listed on the Indonesia Stock Exchange, totaling 43 companies with an observation period starting from 2016 to 2020. Sampling was carried out using a purposive method, namely the researcher determined certain criteria or goals, for the sample to be studied. The unit of analysis using data from 30 companies multiplied by 5 years is 150 financial statements.

\subsection{Types, Data Sources and Data Collection Methods}

The type of data used in this study is secondary data, the data source is the Indonesia Stock Exchange through the http://www.idx.co.id website. The data collection method is the documentation method. The documents that will be used in the research are financial statements that have been audited by public accountants and annual reports, company financial performance profiles, and the fact book of the Indonesia Stock Exchange.

\subsection{Research Variables and Operational Definitions}


implementation of corporate decisions, by management so that it can function as a source of value creation, ensuring the availability of capital adequacy as a buffer for the risk of loan portfolio losses (NPL), operational efficiency to increase profit, and manage credit risk at a minimum level to maintain stable profit growth. Corporate Governance is measured by indicators of the size of the board of commissioners, independent board of commissioners, internal audit committee, external audit committee. Referring to the research of Yulianto et al. (2014).

\subsubsection{Indicators of the Size of the Board of Commissioners}

The size of the Board of Commissioners is the total number of members of the board of commissioners, which is a corporate governance organ whose function is to oversee the policies of the board of directors in carrying out the company's operations and to provide advice and consideration to the board of directors. Referring to the research of Festus et al., (2019) which considers Board Size as an indicator of corporate governance.

\subsubsection{Independent Board of Commissioners}

An independent Board of Commissioners is a board of commissioners who is not a member of management, majority shareholder, official or any position that can influence directly or indirectly the shareholders. The Independent Board of Commissioners is part of the corporate governance structure that functions to oversee the policies of the board of directors in carrying out the company's operations and provide advice to the board of directors. The Audit Committee (AC) is one of the corporate governance control mechanisms in order to improve the quality of the company's financial management and performance. Members of the Audit Committee, consisting of members of the internal audit committee and members of the external audit committee.

\subsubsection{Internal Audit Committee}

The Internal Audit Committee is a member of the Audit Committee who comes from within the company and is formed by the company's management in order to improve the quality of financial accountability and company performance.

\subsubsection{External Audit Committee}

The External Audit Committee is a member of the audit committee who comes from outside the company and is not formed by the company's management. Usually Public Accountants are contracted by companies to evaluate financial accountability made by company management based on traditional accounting principles.

\subsubsection{Endogenous Variable Capital Adequacy ( $\left.\mathbf{Y}_{1}\right)$}

Capital adequacy is one of the important aspects in the implementation of prudential principles in bank management based on regulations issued by the Financial Services Authority. The bank's capital comes from the shareholders (common stock) and the accumulated net profit after tax is not shared or retained earnings. Capital serves as a buffer against the risk of loss due to non-performing loans (NPL). The minimum capital requirement includes two consecutive components, namely: Tier 1 is fully paid up core capital, and Tier 2 is supplementary capital as additional reserve capital.

Capital adequacy indicators used in this study are Debt to Asset Ratio (DAR), Debt to Equity Ratio (DER), and Capital Adequacy Ratio (CAR). Debt to Assets Ratio is the ratio between total debt and total assets. DAR is used to measure how much commercial bank assets are financed with debt (third party deposit funds). Debt to assets ratio (DAR) is calculated by the following formula:

$\mathrm{DAR}=($ Total debt $) /($ Total assets $) \times 100 \%$

Debt to equity ratio (DER) is a comparison between total debt (third party deposits) and total equity, used to measure the ability of equity (own capital) to support total debt or third party deposits. DER is calculated by the following formula:

$\mathrm{DER}=($ Total debt $) /($ Total equity)

Capital adequacy ratio (CAR) is a comparison between total equity (equity) and total risk-weighted assets (RWA) used to measure the level of capital adequacy or ability to cover or buffer the risk of loss on assets that have risk or risk weighted average. Capital adequacy ratio (CAR) is calculated by the following formula:

$\mathrm{CAR}=($ Total Equity $) / \mathrm{RWA} \times 100 \%$

\subsubsection{Credit Risk Variable $\left(\mathrm{Y}_{2}\right)$}

Credit risk is a change in the value of net assets due to changes in the ability of the counter parties to meet agreed obligations. Bank Indonesia Regulation No. 15/12/PBI/2013 concerning Minimum Capital Adequacy Requirements, defines credit risk as the risk of loss due to the failure of the debtor or other party (counter party) in fulfilling obligations to the bank.

NPL or non-performing loans are loans that are categorized as substandard, doubtful, and bad. The higher the NPL ratio, the lower the credit quality of a bank in generating interest income. The NPL ratio indicates the ability of bank management to manage the quality of the loan portfolio disbursed. The better the bank's management in managing the loan portfolio, the lower the NPL and LLP ratio will be, and vice versa. The NonPerforming Loan (NPL) indicator is calculated by the following formula: NPL Gross $(\mathrm{NPLG})=(\mathrm{NPL}) /($ Total loans)

NPL Net $($ NPLN $)=($ NPL $)-$ LLP /(Total loans $)$ 
Loan loss provision (LLP) is a provision for funds or reserves formed to anticipate bank losses due to a decrease in the quality of the loan portfolio. Similar to NPL, higher LLP indicates declining credit quality. The higher the NPL, the higher the LLP so that the subsequent impact will reduce bank income, because the formation of reserves comes from income or Net Interest Income (NII). LLP in the Indonesian banking system uses the term Allowance for Impairment Losses for financial assets, or is called Allowance for Earning Assets Losses . The loan loss provision (LLP) ratio indicator is calculated by the following formula:

Loan Loss Provision (LLP) $=($ LLP) $/($ Total Credit)

\subsubsection{Financial Performance Endogenous Variable (Y3)}

Financial performance is the result of financial achievement that shows the company's ability to manage assets, liabilities, and bank equity to generate maximum profit. Financial performance in this study is measured by indicators: earnings per share (EPS), return on assets (ROA), return on equity (ROE), and net interest margin (NIM). Earning per share (EPS) is the total net profit after tax or net operating profit after tax or net income, divided by the number of shares of common stock issued and fully paid. EPS is calculated by the following formula:

EPS $=($ Net Income $) /($ Common share outstanding $)$

Return on assets is the ratio of net income to total assets within a certain time. ROA is used to measure the company's ability to manage assets to generate profits for the company, so as to increase the company's financial ability to fund projects that have a "positive net present value". Referring to the research Data et al. (2017), ROA is calculated by the following formula:

Return on assets $=($ Earning before interest and tax $) /($ Total assets $) \times 100 \%$

Return on equity (ROE) is the ratio of net profit after tax with total equity within a certain time. ROE is used to measure the company's ability to obtain net profit after tax available to equity owners, so as to increase the wealth of shareholders, as a result investors can assess management efficiency. Referring to the research Data $e t$ al. (2017), Return on equity (ROE) is calculated by the following formula:

Return on equity $=($ Earnig after tax $) /($ Equity $) \times 100 \%$

Net interest margin (NIM) is an indicator that reflects financial performance, which is a comparison between net interest income (net interest income) and average productive assets (interest-earning loan portfolio) in a certain financial reporting period. This ratio is used to measure the bank's ability to earn net interest income, which is the difference between the total interest income and the total interest expense (interest income and interest expenses). NIM is also a measure of a bank's ability to determine funding policies (diversification of funding sources) that affect the cost of fund structure, basic loan interest rates, and credit policies (credit portfolio and lending rate). The higher the NIM indicates that the bank is getting better at managing sources of third party funds (debt), channeling them into a portfolio of credit assets (investment), including a more competitive lending rate policy. NIM is calculated by the following formula:

$\mathrm{NIM}=($ Net interest income $) /($ Average earning assets $) \times 100 \%$

\subsection{Data Analysis Method}

The steps to analyze the data are as follows: 1) Financial ratio analysis, because the data that will be included in the next analysis is data on a ratio scale.

2) Descriptive Statistical Analysis.

Descriptive statistical analysis aims to describe the data that has been collected as it is without intending to draw general conclusions or generalizations. The data depicted in the form of minimum value, maximum value and average value of each indicator, the aim is to see the trend of development of each indicator in the company's financial ratios.

3) Inferential Statistical Analysis

Inferential statistical analysis to test research hypotheses. Inferential statistical analysis in this study uses a structural equation model with a generalized structured component analysis (GSCA) approach. The generalized structured component analysis (GSCA) approach is variance based or component based, predictive model, and can be used to confirm theory with empirical data.

Tests of empirical research models using the GSCA approach developed by Hwang and Takane in 2004, which can be accessed at http://www.sem-gesca.org are as follows: (1) Describe the model of the relationship between research variables based on theory and empirical research, and the analogy of the relationship between research variables is rational. (2) Designing a measurement model to determine latent variable indicators, based on previous empirical theory and research or rationally based on conceptual definitions and operational definitions of variables.

Model the relationship of all variables in the GSCA at zero scale and standardized variance units for measures: (1) Measurement model (outer model) is a model that explains whether indicators measure latent variables. The outer model is often called the outer relation in which each group of indicators measures the latent variable. (2) Structural model (inner model) is a model that explains whether exogenous latent variables affect endogenous 
latent variables and one endogenous latent variable affects other endogenous latent variables. (3) The estimation of the value of the latent variable is based on the weight relation (Esposito et al., 2010).

Steps to analyze data using the GSCA program:

(1) Prepare data files in xlsx (txt) format

(2) Opening the GeSCA program which will be run online.

(3) Upload the data to be analyzed into the GeSCA program.

(4) Draw the analysis model into the GeSCA program (path diagram).

(5) Incorporating indicators into latent variables (assign indicators).

(6) Click run (do analysis) GeSCA.

\section{Research Results}

\subsection{Statistical Description}

Descriptive statistical analysis aims to describe the data that has been collected as it is without intending to draw general conclusions or generalizations. The data described in the form of minimum value, maximum value, average of each indicator forming latent variables, as listed in table 1, are as follows:

Table 1. Development of Research Variable Indicator Values

\begin{tabular}{|l|l|l|l|l|l|l|l|l|}
\hline \multirow{2}{*}{ Variable Indicator } & \multicolumn{7}{|c|}{ Average per Year } & \multicolumn{3}{c|}{ 5 Years Average } \\
\cline { 2 - 9 } Corporate Governance (X) & 2016 & 2017 & 2018 & 2019 & 2020 & Max & Min & Mean \\
\hline SBC & 5 & 5 & 5 & 5 & 5 & 9 & 2 & 5 \\
\hline IBC & 3 & 3 & 3 & 3 & 3 & 5 & 1 & 3 \\
\hline IAC & 3 & 3 & 3 & 3 & 3 & 6 & 1 & 3 \\
\hline EAC & 1 & 1 & 1 & 1 & 1 & 2 & 1 & 1 \\
\hline Capital Adequacy (Y1) & & & & & & & & \\
\hline DAR (\%) & 85 & 85 & 84 & 84 & 84 & 94 & 70 & 84 \\
\hline DER (\%) & 601 & 652 & 614 & 612 & 643 & 1607 & 209 & 632 \\
\hline CAR (\%) & 20.06 & 20.41 & 20.60 & 20.35 & 22.89 & 45.85 & 9.01 & 20.86 \\
\hline Credit Risk (Y2) & & & & & & & & \\
\hline NPLG (\%) & 3.77 & 3.14 & 3.27 & 3.55 & 3.49 & 15.82 & 0.00 & 3.44 \\
\hline NPLN (\%) & 1.86 & 2.05 & 1.91 & 2.15 & 1.62 & 8.54 & 0.00 & 1.92 \\
\hline LLP (\%) & 2.34 & 2.27 & 2.18 & 2.20 & 3.25 & 7.70 & 0.00 & 2.45 \\
\hline Financial Performance (Y) & & & & & & & & \\
\hline EPS (\%) & 111.71 & 190.67 & 159.91 & 179.19 & 111.91 & 1371.32 & -485 & 151.81 \\
\hline ROA (\%) & 0.35 & 0.90 & 1.39 & 1.25 & 0.79 & 4.00 & -11.15 & 0.94 \\
\hline ROE (\%) & 0.79 & 5.06 & 6.85 & 5.10 & 3.87 & 23.08 & -65.76 & 4.33 \\
\hline NIM (\%) & -3.04 & 5.01 & 4.91 & 4.38 & 3.86 & 40.92 & -315.06 & 3.03 \\
\hline
\end{tabular}

Source of data: IDX company financial report and annual report on the website http://www.idx.co.id

\subsection{Statistical Analysis With GSCA}

The Fit Model test show the FIT value of 0.548 means that the dependent latent variable can be explained by the independent latent variable in the structural model by $54.8 \%$, or in other words the information contained in the data can be explained by $54.8 \%$ by the model, while the remaining $45.2 \%$ is explained by other variables that have not been included in the research model and errors. The FIT value shows the predictive-relevance value of the total variance explained by all variables in the structural model. The FIT value ranges from 0 to 1 . The closer to 1 , the variance of all variables in the model can explain a lot of information by empirical data. The value of AFIT (adjusted FIT) is almost the same as FIT, but it takes into account the complexity of the model. AFIT can be used to compare existing models. Considering that more variables in the model will affect the FIT value to be greater because of the diversity of the data, and the model is getting more complex, so to adjust to the existing variables, the corrected FIT (AFIT) can be used.

Considering that more than one independent latent variable in the model will affect the dependent latent variable, it is more appropriate if the interpretation of the model accuracy uses the corrected FIT value (AFIT). The AFIT value of 0.547 means that the dependent latent variable can be explained by the independent latent variable in the model by $54.7 \%$, or in other words the information contained in the data can be explained by $54.7 \%$ by the model, while the remaining $45.3 \%$ is explained by other variables. which have not been included in the research and error model.

\subsubsection{Outer Model Test Results}

Outer model (Measurement Model) which explains the relationship between latent variables and their manifest indicators or variables (measurement model). The outer weight value shows the weight value of each indicator as 
a measure of the latent variable. The indicator with the largest outer weight indicates that the indicator is the strongest or dominant measure of the variable. The results of the outer weight indicator of the seven measured latent variables, obtained through the GSCA bootstrap calculation which also produces a critical ratio (CR) value similar to the statistical $\mathrm{T}$ value, if the weight value is above 0.4 and the $\mathrm{CR}$ value is greater than $1.96 \mathrm{~T}$ table, it is decided significant. The detailed test results are as in table 2, as follows:

Table 2. Measurement Model Test Results (Outer Model)

\begin{tabular}{|c|c|c|c|c|c|c|c|c|}
\hline \multirow{2}{*}{\multicolumn{4}{|c|}{ Indicator }} & \multicolumn{4}{|c|}{ Loading } & \multirow[t]{2}{*}{ Information } \\
\hline & & & & Estimate & SE & $\mathrm{CR}(\mathrm{t})$ & P-Vaue & \\
\hline \multicolumn{8}{|c|}{ Measurement Model of Corporate Governance Variables (X) } & \\
\hline \multicolumn{4}{|c|}{ Size of the Board of Commissioners (SBC) } & 0.872 & 0.018 & $47.77^{*}$ & 0.00 & Sgnificant \\
\hline \multicolumn{4}{|c|}{ Independent Board of Commissioners (IBC) } & 0.902 & 0.010 & $86.26^{*}$ & 0.00 & Sgnificant \\
\hline \multicolumn{4}{|c|}{ Internal Audit Committee (IAC) } & 0.673 & 0.046 & $14.5^{*}$ & 0.00 & Sgnificant \\
\hline \multicolumn{4}{|c|}{ External Audit Committee (EAC) } & 0.517 & 0.081 & $6.41^{*}$ & 0.00 & Sgnificant \\
\hline \multicolumn{8}{|c|}{ Measurement Model of Capital Adequacy Variable ( $\left.Y_{1}\right)$} & \\
\hline \multicolumn{4}{|c|}{\begin{tabular}{|l|l} 
Debt to Asset Ratio & \\
\end{tabular}} & 0.927 & 0.017 & $54.31^{*}$ & 0.00 & Sgnificant \\
\hline \multicolumn{4}{|c|}{ Debt to Equity Ratio } & 0.916 & 0.011 & $80.96^{*}$ & 0.00 & Sgnificant \\
\hline \multicolumn{4}{|c|}{ Capital Adequacy Ratio } & 0.840 & 0.025 & $33.46^{*}$ & 0.00 & Sgnificant \\
\hline \multicolumn{9}{|c|}{ Measurement Model of Credit Risk Variable $\left(\mathrm{Y}_{2}\right)$} \\
\hline \multicolumn{4}{|c|}{\begin{tabular}{|l|l} 
NPLG &
\end{tabular}} & 0.952 & 0.032 & $29.78^{*}$ & 0.00 & Sgnificant \\
\hline \multicolumn{4}{|l|}{ NPLN } & 0.835 & 0.035 & $24.01^{*}$ & 0.00 & Sgnificant \\
\hline \multicolumn{4}{|l|}{ LLP } & 0.579 & 0.074 & $7.77^{*}$ & 0.00 & Sgnificant \\
\hline \multicolumn{9}{|c|}{ Measurement Model of Financial Performance Variables $\left(\mathrm{Y}_{3}\right)$} \\
\hline Earning Per & lare & & & 0.680 & 0.036 & $19.07^{*}$ & 0.00 & Sgnificant \\
\hline Return On A & ets & & & 0.960 & 0.016 & $60.99^{*}$ & 0.00 & Sgnificant \\
\hline Retrun On E & iity & & & 0.904 & 0.018 & $51.63^{*}$ & 0.00 & Sgnificant \\
\hline Net Interest & $\operatorname{argin}$ & & & 0.626 & 0.073 & $8.53^{*}$ & 0.00 & Sgnificant \\
\hline $\mathrm{CR}^{*}=$ Sgnif & ant at 0.05 & & & & & & & \\
\hline Source: GSC & analysis re & Its processe & 2021 & & & & & \\
\hline $\begin{array}{l}\text { Based on the } \\
\text { Table 3. Str }\end{array}$ & $\begin{array}{l}\text { esults of the } \\
\text { tural Mod }\end{array}$ & $\begin{array}{l}\text { SCA analy } \\
\text { Test Resul }\end{array}$ & $\begin{array}{l}\text { a teste } \\
\text { Inner I }\end{array}$ & $\begin{array}{l}\text { ed hypothes } \\
\text { Model) }\end{array}$ & is model & obtained & as shown il & ble 3 below: \\
\hline Hypothesis & Path & Path Coef & nts & & & & & \\
\hline & & Estimate & $\mathrm{SE}$ & CR & P-Val & & Info & ation \\
\hline H1 & $X \rightarrow Y 1$ & 0.309 & 0.067 & $4.64^{*}$ & 0.00 & Sig & ificant & H1 accepted \\
\hline $\mathrm{H} 2$ & $X \rightarrow Y 2$ & 0.070 & 0.089 & 0.78 & 0.43 & No & significant & H2 rejected \\
\hline H3 & $\mathrm{X} \rightarrow \mathrm{Yj}$ & 0.228 & 0.063 & $3.64^{*}$ & 0.00 & Sig & ificant & H3 accepted \\
\hline $\mathrm{H} 4$ & $\mathrm{Y} 1 \rightarrow \mathrm{Y} 2$ & -0.178 & 0.044 & $4.06^{*}$ & 0.00 & Sig & ificant & H4 accepted \\
\hline H5 & $\mathrm{Y} 1 \rightarrow \mathrm{Y} 3$ & 0.128 & 0.055 & $2.32^{*}$ & 0.02 & Sig & ificant & H5 accepted \\
\hline H6 & $\mathrm{Y} 2+\mathrm{Y} 3$ & -0.720 & 0.024 & $29.52^{*}$ & 0.00 & Sig & ificant & H6 accepted \\
\hline $\mathrm{CR}^{*}=$ Sign & ant at 0,0 & & & & & & & \\
\hline
\end{tabular}

\section{Discussion}

\subsection{The Effect of Good Corporate Governance on Capital Adequacy}

Corporate governance $(\mathrm{X})$ has a significant effect on capital adequacy (Y1), the path coefficient value is 0.309 ; $\mathrm{CR}$ value 4.64* greater than 1.96; at the level of $\mathrm{P}=0.05$. The statistical evidence shows that the path coefficient is positive and significant. A positive path coefficient means that improving the corporate governance structure will ensure and increase the availability of capital adequacy. The path coefficient of the influence of corporate governance on the capital structure of 0.309 means that every improvement in the corporate governance structure of 1 unit will result in an increase in the capital structure and availability of capital adequacy of 0.233 rupiah. The test results show sufficient empirical evidence to accept hypothesis 1, which states that corporate governance has an influence on capital adequacy. The theoretical implication of this empirical is that corporate governance has an influence in determining capital adequacy, namely good corporate governance will result in an increase in the capital structure and availability of capital adequacy.

4.2 The Effect of Corporate Governance on Credit Risk

Corporate governance $(\mathrm{X})$ has no significant effect on credit risk $\left(\mathrm{Y}_{2}\right)$, the path coefficient value is 0.070 ; $\mathrm{CR}$ 
value 0.78 is greater than 1.96 ; at the level of $\mathrm{P}=0.05$. The test results show that there is insufficient empirical evidence to accept hypothesis 2 , which states that corporate governance has an influence on credit risk, so the statistical decision for hypothesis 2 is rejected. The effect of corporate governance on credit risk cannot be generalized to the study population, because it is not statistically significant, which means it only applies to certain sample cases. Corporate governance is not able to determine credit risk, because credit risk management is an operational responsibility that must be carried out by company management in order to control risk. Management must make the right decisions in controlling credit risk, so as not to adversely affect the company's financial performance, because credit risk has a negative effect on financial performance.

\subsection{The Effect of Corporate Governance on Financial Performance}

Corporate governance $(\mathrm{X})$ has a significant effect on financial performance $\left(\mathrm{Y}_{3}\right)$, the path coefficient value is 0.228 ; CR value $3.64 *$ greater than 1.96 ; at the level of $\mathrm{P}=0.05$. The statistical evidence shows that the path coefficient is positive and significant. The path coefficient is positive, meaning that improvements in the corporate governance structure will improve the bank's financial performance. The path coefficient of the influence of corporate governance on the bank's financial performance is 0.228 which means that every improvement in corporate governance by 1 unit will result in an increase in the bank's financial performance of 0.228 rupiah.

The test results show sufficient empirical evidence to accept hypothesis 3 , which states that corporate governance has a direct and mediated effect of capital adequacy on financial performance. The effect of corporate governance on bank financial performance is also mediated by capital adequacy. The theoretical implication of this empirical is that corporate governance has an influence in determining financial performance, namely good corporate governance will lead to an increase in financial performance. The findings of this study confirm the research of Emmanuel and Hodo (2012), Danoshana and Ravivathani (2013) found board size and audit committee size have a positive effect on company performance, Vo and Phan (2013) elements of corporate governance such as CEO duality, the presence of female board members, work experience of members of the board of directors and compensation of members of the board of commissioners. Finding that all elements have a positive influence on firm performance but board size has a negative effect on firm performance. Latif et al., (2013) found that board size has a significant positive effect on firm performance.

The findings of this study do not support research by Olatunji and Ojeka (2011) examining the role of nonexecutive directors on financial performance and finding that non-executive directors and return on equity are negatively correlated with each other. The findings indicate that a greater number of outside directors has a detrimental effect on financial performance. Nyamonogo and Temesgen (2013) board size has a negative effect on the performance of company directors.

Vo and Phan (2013) found that board size has a negative effect on firm performance. Coleman and Biekpe (2006) examined the relationship between corporate governance and financial performance in Ghana and found that board size and CEO duality had no significant relationship with performance.

Gill and Mathur (2011) found that board size has a negative effect on financial performance. Research by Danoshana and Ravivathani (2013) found that the size of the board and the size of the audit committee have a positive effect on company performance, the frequency of board meetings has a negative effect on company performance.

\subsection{The Effect of Capital Adequacy on Credit Risk}

Capital adequacy (Y1) has a significant effect on credit risk (Y2), path coefficient value -0.178; CR value 4.06* greater than 1.96; at the level of $\mathrm{P}=0.05$. The result of statistical evidence shows the path coefficient is negative and significant. The path coefficient is negative, meaning that capital adequacy will reduce credit risk. The path coefficient of the effect of capital adequacy on credit risk is -0.178 which means that every improvement in capital adequacy of 1 unit will result in a decrease in bank credit risk of -0.178 rupiah. The test results show that there is sufficient empirical evidence to accept hypothesis 4, which states that capital adequacy has an influence on credit risk. The theoretical implication of this empirical is that capital adequacy has an influence in determining bank credit risk, namely that capital adequacy will result in a decrease in bank credit risk.

The findings of this study support the research findings of Deelchand and Padgett (2009) on cooperative banks in Japan, and Aymen (2015) on Tunisian banks which found that the effect of capital adequacy on credit risk was negative. Capital adequacy ratio is calculated by dividing total shareholder equity by total assets. A high capital adequacy ratio indicates that the owner of the bank has a larger share than creditors in the bank's assets. Credit risk is obtained by dividing the loan loss reserve by the total loan portfolio. A high credit risk index indicates that banks have a higher level of problematic loans (Mendoza and Rivera, 2017).

The findings of this study confirm and support the Bearing Risk Theory developed by Hawley (1900) explaining that an important function of an entrepreneur is taking risks, a function that cannot be delegated to others. Hawley argues that profit is the reward for taking the risk. This theory further states that some risk is 
inherent in every business enterprise in view of the speculative nature of the business. So, management must bear the risk to earn profit in return for taking risk in the banking business.

The banking sector business cannot be separated from the issue of risk (risk taking), namely the potential for failure and otherwise the banking system is not in a position to encourage growth in the real economic sector (Greenspan, 1996). The theory that underlies the relationship of risk in the banking business (credit risk) with capital adequacy is in accordance with the "Capital Buffer Theory" which states that excess capital from a CAR position of at least $8 \%$, is intended as a "risk buffer" and reduces the possibility of financial difficulties or bank failures (Deelchand and Padgett, 2009).

Capital Buffer Theory has been confirmed empirically from the results of banking studies in the United States, Switzerland and Japan, in the period between 1992-2003 (Deelchand and Padgett, 2009). Jokipii and Maline (2009) stated that the Capital Buffer Theory predicts that banks will maintain a level of capital above the minimum requirement (a buffer of capital), distinguishing the pattern of long-term and short-term relationships between credit risk and capital adequacy. In the long term the relationship between credit risk and capital adequacy will be positive, in the short term the relationship will be positive if the bank has a capital adequacy above the minimum, and vice versa if the bank only has a minimum level of capital adequacy, then the relationship between credit risk and capital adequacy will be negative.

The findings of this study do not support the research of Bichsel and Blum (2002) on banking in Switzerland which found that capital adequacy has a positive effect on credit risk, which states that the higher the capital adequacy, the higher the level of credit risk faced. Research by Altumbas et al., (2007); Maurin and Toivanen (2012) the relationship between credit risk and capital adequacy is positive.

\subsection{The Effect of Capital Adequacy on Financial Performance}

Capital adequacy (Y1) has a significant effect on financial performance (Y3), the path coefficient value is 0.128 ; $\mathrm{CR}$ value $2.32 *$ greater than 1.96; at the level of $\mathrm{p}=0.05$. Capital adequacy has an influence on financial performance mediated by credit risk based on the mediation test according to the Sobel statistic test, which is 4,009 , which is greater than $\mathrm{t}$ table 1.96 at the level of $\mathrm{P}=0.05$. The statistical evidence shows that the path coefficient is positive and significant.

The path coefficient is positive, meaning that improvements in the corporate governance structure will improve the bank's financial performance. The path coefficient of the effect of capital adequacy on financial performance of 0.128 can be interpreted that every improvement in capital adequacy of 1 unit will result in an increase in bank financial performance of 0.128 rupiah. The test results show sufficient empirical evidence to accept hypothesis 5, which states that capital adequacy has a direct and mediated effect of credit risk on financial performance. The theoretical implication of this empirical is that capital adequacy has an influence in determining the financial performance of a bank, namely that capital adequacy will lead to an increase in the bank's financial performance. Capital adequacy has a direct and mediated effect of credit risk on financial performance. Adequate capital is able to reduce credit risk and improve financial performance, because credit risk which negatively affects financial performance has been successfully reduced.

This study confirms and supports the research concept of Akhtar et al. (2011) also concluded that in six Islamic banks in Pakistan, capital adequacy has a significant positive effect on ROA and ROE. Scott and Arias (2011) who found that the ratio of capital to total assets has a positive relationship with ROE in five US banks. Obamuyi (2013) used a fixed effect regression model to analyze the data of 20 banks in Nigeria found that capital adequacy has a significant positive effect on ROA. Roman and Danuletiu (2013) used multiple linear regression to examine 15 commercial banks in Romania, finding that capital adequacy has a significant positive relationship with financial performance.

This study does not support the research findings of Mendoza and Rivera, 2017) finding that capital adequacy does not have a significant effect on the rural financial performance of banks in the Philippines. The only study with unique results is that of Poudel (2012) who found that the capital adequacy ratio has a negative relationship with the financial performance of 31 Nepalese banks.

\subsection{The Effect of Credit Risk on Financial Performance}

Credit risk has a significant effect on the financial performance of bank companies (Y3), the path coefficient value is -0.720 ; $C R$ value $29.52 *$ greater than 1.96 ; at the level of $p=0.05$. The result of statistical evidence shows the path coefficient is negative and significant. The path coefficient is negative, meaning that an increase in credit risk will reduce the financial performance of bank companies. The path coefficient of the influence of credit risk on the bank's financial performance is -0.720 which means that every increase in credit risk of 1 rupiah will result in a decrease in the bank's financial performance of -0.720 rupiah.

The test results show sufficient empirical evidence to accept hypothesis 6 , which states that credit risk has a significant effect on financial performance. The theoretical implication of this empirical is that credit risk has an influence in determining financial performance, namely credit risk will reduce financial performance. Any 
increase in credit risk that appears in the increase in the NPL ratio, and an increase in the allowance for impairment losses or loan loss provision (LLP), will reduce the financial performance of bank issuers listed on the Indonesia Stock Exchange. The decline in financial performance was caused by the increase in the number of LLP which became a deduction factor for the amount of operating profit for the year from each bank. The theoretical meaning of this empirical finding is that credit risk affects financial performance.

Credit risk has an effect on profitability, operational efficiency and stock prices of banks, because an increasing NPL and LLP ratio will directly reduce the bank's potential income, and be an indication that the bank is relatively inefficient. This condition gives a negative signal to the market which causes investors to sell banking shares, which then has an impact on the decline in the share price. If the NPL and LLP ratios decrease or improve, it will have a positive effect on increasing bank income (profitability), the level of operational efficiency and provide a positive signal to the market so that investors will have incentives to buy these shares (Amidu and Robert, 2006; Mbarek and Hmaied, 2011; and Epure and Esteban, 2013).

The risk itself is the result of investment decisions and funding decisions of the company. Risk is the position of the actual return on investment that is different from the expected return (Alshatti, 2015). Risk means the possibility of losing the original investment and the amount of interest accumulated in it. Credit risk is the risk that the borrower defaults and does not honor his obligations to pay the debt. It can happen when partners are unable to pay or cannot pay on time.

The findings of this study confirm and support the research concept of Alshatti (2015) that credit risk management has a significant effect on the financial performance (ROA and ROE) of Jordanian commercial banks, further concluding that credit risk management indicators (bad credit / gross loans, provisions for loss facilities / net facilities) and leverage ratio) has a significant effect on the financial performance of Jordanian commercial banks. Mendoza and Rivera (2017) on the rural banking sector in the Philippines, also support the empirical findings of previous research studies conducted by Epure and Esteban (2013) on Costarika banking and Amidu and Robert (2006) on Ghanaian banking, both of which states that credit risk affects financial performance (profitability and ROA) in a negative direction. The findings of this study do not support the research of Christaria and Kurnia (2016) which found that credit risk (Non Performing Loans) has an insignificant effect on the financial performance (ROA) of commercial banks in Indonesia.

\section{Conclusion}

1) Corporate governance has a significant influence on capital adequacy, because good corporate governance results in an increase in the capital structure and availability of capital adequacy.

2) Corporate governance has no significant influence on credit risk. The effect of corporate governance on credit risk cannot be generalized to the study population, because it is not statistically significant, which means it only applies to certain sample cases. Corporate governance is not able to determine credit risk, because credit risk management is an operational responsibility that must be carried out by company management in order to control risk.

3) Corporate governance has a significant influence on financial performance, because good corporate governance will make the company more able to operate and invest optimally, thereby generating maximum profit and resulting in an increase in financial performance. The effect of corporate governance on bank financial performance is also mediated by capital adequacy.

4) Capital adequacy has a significant effect on credit risk, because capital adequacy for the company's operations and investments will result in a reduction in bank credit risk.

5) Capital adequacy has a significant influence on financial performance, because capital adequacy for the company's operations and investments will result in an increase in the bank's financial performance. Capital adequacy has a direct and mediated effect of credit risk on financial performance. Adequate capital is able to reduce credit risk and improve financial performance, because credit risk which negatively affects financial performance has been successfully reduced.

6) Credit risk has a significant influence on the financial performance of value banks, because credit risk will cause the company to lose and reduce financial performance.

\section{Recommendations}

1) Future research can add other variables that have not been included in this research model, to obtain a more comprehensive research model. Integrating financial statement data and other relevant information to overcome the limitations of historical data in financial statements. Follow-up research can be carried out elsewhere for a longer time, or replace other research objects.

2) For companies on the Indonesia Stock Exchange and investors, the results of this study are expected to be useful input in making decisions or financing policies for a company. Practically for companies on the Indonesia Stock Exchange and investors, the following can be recommended: Management must consider corporate governance, capital adequacy, credit risk and financial performance. Corporate corporate 
governance can be a reference in determining the funding mechanism, whether to use internal funds or external funds. Companies can use internal funds first before external funds, because internal funds are free of additional interest costs. Considering credit risk, because credit risk is the uncertainty of receiving receivables and bank income which has a negative impact on financial performance and firm value. Using debt at the lowest possible cost level in order to increase profits and financial performance. Maintain and improve financial performance, because investors will appreciate the shares of companies that have high financial performance at the highest price. Must combine financial statement data and other relevant information for analysis purposes in producing more accurate predictions. To overcome the limitations of financial statements, because financial statement data is historical data or past data. If there is an error in the disclosure in the financial statements, it will result in the prediction results being inaccurate.

\section{References}

Abdelrahim K. E. (2013). Effectiveness of Credit Risk Management of Saudi Banks in the Light of Global Financial Crisis: A Qualitative Study. Asian Transactions on Basic and Applied Sciences, 3 (2), pp. 73-91. Available at: http://asian-transactions.org.

Adeusi S.O., Akeke N.I., Adebisi O.S and Oladunjoye O. (2013). Risk Management and Financial Performance of Banks in Nigeria, Journal of Business and Management, 14 (6), pp. 52-56.

Aghion P and J. Bolton. (1992). An incomplete contracts approach to financial contracting. Review of Economic Studies, 59, pp. 473-494.

Akhtar M. F., Ali K and Sadaqat S. (2011). Factors influencing the profitability of Islamic banks of Pakistan. International Research Journal of Finance and Economics, 66, 125-132.

Alchian A. A and Demsetz H. (1972). Production, information costs and economic Organisation. American Economic Review, 62(1), 772-795.

Alshatti Ali Sulieman. (2015). The effect of credit risk management on financial performance of the Jordanian commercial banks. Investment Management and Financial Innovations, 12 (1): 338-345.

Altumbas,Yener, Santiago Carbo, Edward P.M. Gardener and Philip Molyneux. (2007). Examining the relationship between capital, risk and efficiency in European Banking. European Financial Management, Vol.13(1):49-70.

Amidu Mohammed and Robert Hinson. (2006). Credit risk, capital structure and lending decisions of banks in Ghana. Banks and bank system, Vol.1. Issue 1, 2006.

Anderson C. W., Becher D. A and Campbell T. L. (2004). Bank mergers: The market for bank CEOs, and managerial incentives. Journal of Financial Intermediation, 27(3), 89-102.

Aymen. (2015). The relasionship between capital and bank risk, evidence from Tunisia.

Bank Indonesia. (2013). Bank Indonesia Regulation No.15/12/PBI/2013, Concerning the Minimum Capital Adequacy Requirement for Commercial Banks. State Gazette of the Republic of Indonesia No. 223 DPNP, Year 2013.

Berrios M. R. (2013). The Relationship between Bank Credit Risk and Profitability and Liquidity. The International Journal Of Business And Finance Research, 7 (3), pp. 105-118. Available at: SSRN: http://ssrn.com/abstract=2149816. 8 .

Bischsel and Blum. (2002). The relationship between risk and capital in Swiss commersial banks: A Panel Study, Working Paper No. 02.04, Sptember, 2002.

Christaria Fiola and Kurnia, Ratnawati. (2016).The Impact of Financial Ratios, Operational Efficiency and NonPerforming Loan Towards Commercial Bank Profitability. Accounting and Finance Review, 1 (1): 43-50.

Ciancianelli P and J. Gonzales. (2000). Corporate governance in banking: A conceptual Framework. Social Science Research Network Electronic Paper Collection.

Coase R. H. 1937. The nature of the firm. Economica, No. 4, pp 386-405.

Coleman Anthony Kyereboah and Biekpe Nicholas. (2008). The Relationship Between Board Size, Board Composition, CEO Duality and Firm Performance: Experience from Ghana, Pp 1-19. https://www.researchgate.net/publication/228715058.

Data Ari, Alhabsji Taher, Rahayu Sri Mangesti, and Handayani Siti Ragil. (2017). Effect of growth, liquidity, business risk and asset usage activity, toward capital structure, financial performance and corporate value (Study at manufacturing companies listed in Indonesia Stock Exchange in 2010-2015). European Journal of Business and Management, Vol.9, No.24, 2017. Pp 9-25.

Deelchan Tara and Padgett Carol. (2009). The relationship between Risk, Capital and Efficiency: Evidence from Japanese Cooperative Banks., ICMA Centre discussion Paper in Finance, DP. 2009-12.

Danoshana S and Ravivathani T. (2013). The impact of the corporate governance on firm performance: A study on financial institutions in Sri Lanka. Merit Research Journal of Accounting, Auditing, Economics and Finance Vol. 1(6) pp. 118-121, December, 2013.

Dao Binh and Hoang Giang. (2012). Corporate governance and performance in Vietnamese Commercial Banks. 
Journal of Economics and Development, Vol. 14 (2): pp. 72 - 95.

Dao Binh and Pham Hoa. (2015). Corporate governance and bank credit risk: default probability, distance to default. SSRN Electronic Journal. June 2015, pp1-22.

Economic Times Bureau. (2010). What is Capital Adequacy Ratio?. from http://economictimes.indiatimes.com/all-about-capital-adequacy-ratio/what-is-capital-adequacyratio/slideshow/6222228.cms

Emmanuel A and Hodo R. (2012). Does Corporate Governance affect Bank Profitability? Evidence from Nigeria. American International Journal of Contemporary Research, 2 (7), 135-145.

Epure M and Esteban L. (2013). Monitoring bank performance in the presense of risk. Barcelona GSE Working Paper Series, No.613, JEL Classification G21,G28, G3, M1, M2.

Esposito Vinzi V., Chin W.W., Henseler J and Wang H. (2010). Handbook of. Partial Least Squares. Concepts, Methods and Applications. Springer. New York.

Fama E. F and Jensen Michael. (1983). Separation of ownership and control. Journal of Law and Economics, No.26, pp. 301-325.

Festus Adegbie Folajimi, Akintoye Iranola, Rufus and Ashaolu A. Olawale. (2019). Corporate governance and financial stability of nigeria quoted deposit money banks. International Journal of Business and Management Review, Vol.7, No.5, pp.38-60.

Flamini V., McDonald C and Schumacher L. (2009). The determinants of commercial bank profitability in SubSaharan Africa IMF Working Paper, 09/15 (january2009), pp 1-30.

Gill Amarjit and Mathur Neil. (2011). The Impact of Board Size, CEO Duality, and Corporate Liquidity on the Profitability of Canadian Service Firms. Journal of Applied Finance \& Banking, vol.1, no.3, 2011, pp 83-95.

Greenspan Alen. (1996). Annual Convention of the American Banker Association 1996.

Gompers, P.A., J.L. Ishii and A. Metric. (2003). Corporate governance and equity prices. Quarterly Journal of Economics, Vol.118, No.1,pp. 107-155.

Haneef Shahbaz., Tabassum Riaz., Ramzan Muhammad., Rana Mansoor Ali., Ishaq Hafiz Muhammad and Karim Yasir. (2012). Impact of Risk Management on Non-Performing Loans and Profitability of Banking Sector of Pakistan. International Journal of Business and Social Science. Vol. 3, No. 7, pp 307-315.

Hwang H and Takane Y. (2004). Generalized Structured Component Analysis. Psychometric, 69 (1) : 81-99.

Hawley F. B. (1900). Enterprise and profit. Quarterly Journal of Economics, 15(1), 75-105.

Jensen Michael and Meckling William. (1976). Theory of the firm: Managerial behavior, agency costs and ownership structure. Journal of Financial Economics, 3, pp 305-360.

Jokipii T and Milne, A. (2009). Bank capital buffer and risk adjusment decisions. Swiss National Bank Working Papers, 2009-9.

Kaaya I and Pastory D. (2013). Credit Risk and Commercial Banks Performance in Tanzania: a Panel Data Analysis. Research Journal of Finance and Accounting, 4 (16), pp. 55-63.

Kumar Anshuman and Nihalani Yatin. (2014). The Effect of Corporate Governance on the Performance of Indian Banks. International Journal Of Innovative Research \& Development, Vol 3 Issue 8, pp. 270-285.

Latif Bilal., Shahid Muhammad Naeem., Haq Muhammad Zia Ul., Waqas Hafiz Muhammad And Arshad Arbab. (2013). Impact of Corporate Governance on Firm Performance: Evidence from Sugar Mills of Pakistan. European Journal of Business and Management, Vol.5 (1): 51-59.

Maurin, L and Toivanen M. (2012). Risk, capital buffer and bank lending a granular approach to the adjusment of Euro Area Bank. Working Paper Series, No 1499 / november 2012, http://www.ecb.europa.eu.

Mbarek Lassaad and Hmaied D M. (2011). Stock market assessment of bank risk, Evidence from the Magreb Region. Economic Research Forum, March 2012. ERF $18^{\text {th }}$ Annual Conference, Cairo.

Mendoza, Rufo and Rivera, John Paolo R. (2017). The effect of credit risk and capital adequacy on the profitability of rural banks in the Philippines. Scientific Annals of Economics and Business, 64 (1): 83-96.

Milton Friedman. (1970) The social responsibility of business is to enhance its profits. New York Times 32(13): $122-126$

Nawaz M. and Munir S. (2012). Credit risk and the performance of Nigerian. Interdisciplinary Journal of Contemporary Research in, 4 (7), pp. 49-63.

Naceur S. B. (2003). The determinants of the Tunisian banking industry profitability: panel evidence. Universite Libre de Tunis Working Paper, 1-17.

Nyamongo Esman Morekwa and Temesgen Kebede. (2013). The effect of governance on performance of commercial banks in Kenya: A panel study. Corporate Governance International Journal of Business in Society, 13(3), June 201

Obamuyi T. M. (2013). Determinants of banks' profitability in a developing economy: Evidence from Nigeria. Organizations and Markets in Emerging Economies, 4(2), 97-111.

Ogboi Ch and Unuafe O. K. (2013). Impact of Credit Risk Management and Capital Adequacy on the Financial Performance of Commercial Banks in Nigeria. Journal of Emerging Issues in Economics, Finance and 
Banking, 2 (3), pp. 703-717.

Olatunji Olubukunola 'Ranti and Ojeka Stephen. (2011). The role of non-executive directors in the profitability of banks: a study of universal banks in Nigeria. International Journal of Business and Management, Vol. 6, No. 2; pp 248-257.

Poudel R. P. S. (2012). The impact of credit risk management on financial performance of commercial banks in Nepal. International Journal of Arts and Communication, 1 (5), pp 9-15.

Roman A and Danuletiu A. E. (2013). An empirical analysis of the determinants of bank profitability in Romania. Annales Universitatis Apulensis Series Oeconomica, 15(2), 580-593.

Ross S. (1973). The economic theory of agency: The principal problem. American Economic Review, 63(2): $134-139$

Sanda A. U., Garba T and Mikailu A. S. (2005). Corporate governance mechanisms and fir financial performance in Nigeria. Final Report Presented to the Biannual Research Workshop of the AERC, Nairobi, Kenya, 12(1), 24-29.

Scott J. W and Arias J. C. (2011). Banking profitability determinants. Business Intelligence Journal, 4(2), 209230.

Shleifer A and Vishny R.W. (1997). A survey of corporate governance. Journal of Finance, No.52, pp. 737-783.

Todorović. (2013). Impact of Corporate Governance on Performance of Companies. Montenegrin Journal of Economics, vol. 9, pp. 47- 53.

Vo D and Phan T. (2013). Corporate Governance and firm performance: Empirical evidence from Vietnam. Retrieved from http//murdoch.edu.au/School-of Management and-Governance /_document/AustralianConference-of-Economists/Corporate-governance-and-firm- performance.pdf.

Yulianto Arief ., Suhadak., Darminto and Siti Ragil Handayani. (2014). The role of corporate governance, dividend policy, and capital structure on ownership structure toward the firm value. European Journal of Business and Management, 6 (8): 134-141.

Williamson O. E. (1975). Markets And Hierarchies. MacMillan, New York.

Williamson, O. E. (1985). The Economic Institutions Of Capitalism. The Free Press, New York. www.Investopedia.com, Dec 23, 2020. 